\title{
Cellulosic Cyperus esculentus L. as a filtrate loss modifier in field applicable aqueous and non-aqueous drilling fluids
}

\author{
Emmanuel Emeka Okoro ${ }^{1} \cdot K_{\text {Kevin C. Igwilo }}^{2} \cdot$ Kelvin Ifeka ${ }^{1} \cdot$ Ikechukwu Stanley Okafor $^{3} \cdot$ Idowu Sangotade $^{1}$
}

Received: 7 June 2018 / Accepted: 2 November 2018 / Published online: 16 November 2018

(c) The Author(s) 2018

\begin{abstract}
The design and formulation of drilling fluids require additives that are cost-effective and environmental friendly in line with international best practices. This study was conducted to investigate the potentials and effects of Cyperus esculentus (Tiger Nut) as a filtrate loss modifier in field applicable aqueous and non-aqueous drilling fluids. Sixteen (eight aqueous and eight non-aqueous) drilling fluid systems were formulated, four aqueous and non-aqueous had Cyperus esculentus as a filtration additive, while the others do not contain the additive. The rheological properties, as well as the fluid filtration properties of the drilling muds, were investigated and compared with standard drilling mud. To ascertain validity, the results obtained were validated with the classic filtration model to ensure fit. Results obtained showed that the formulated mud systems had rheological properties that favored the suspension and transportation of drill cuttings, as well as the prevention of flocculation and clogging of drill strings. The rheological properties also showed a progressive trend as the concentrations of the additive were increased from 2 to $8 \mathrm{ppb}$. It was also further observed from the API and HPHT filter press test that the increase in the concentration of the additive exhibits a progressive trend that can be compared with the standard. In addition, it was observed from the classic filtration model that the experimental results from both mud systems were fit for the adopted model.
\end{abstract}

Keywords Aqueous and non-aqueous mud systems · Filtration loss · Cyperus esculentus - Additive · API and HPHT filter press test

\section{Introduction}

Aqueous and non-aqueous drilling fluids are essential to oil and gas well drilling operations. Though they are of different compositions, their functions during circulation and circulation stop while drilling are the same. They provide a good initial well control of the subsurface pressure using their density and any additional pressure acting on the liquid column. Typically, they flow from the drill strings to the bit, out to the annulus and support in removing the drill cuttings from the wellbore to the surface (Agwu and Akpabio 2018; Adams and Eustes 2011). The performance of their

Emmanuel Emeka Okoro

emeka.okoro@covenantuniversity.edu.ng

1 Petroleum Engineering Department, Covenant University, Ota, Nigeria

2 Petroleum Engineering Department, Federal University of Technology Owerri, Owerri, Nigeria

3 Petroleum Engineering Department, Nile University, Abuja, Nigeria functions depends on the properties of the drilled formation and drilling fluids. It is known that the design and characteristics of a particular drilling fluid depend on the complexity of the wellbore being drilled, the pressure and temperature of the subsurface, and the related logistics. To prevent in situ fluids from entering the well, the hydraulic pressure of the drilling fluid column must be greater than the fluid pressure in the formation pores (Okoro and Dosunmu 2014; Alsaba et al. 2014; Agwu and Akpabio 2018; Caenn et al. 2011).

This differential pressure creates a force for the drilling fluids to move along the borehole wall into the permeable formations, sometimes causing loss of drilling fluids to these permeable zones. Huge loss of drilling fluid in the formation is associated with fractures because drilling fluid solid materials are often filtered onto the formation wall in the wellbore. Thus, forming a filter cake through which the only filtrate can pass (Luo et al. 2017; Abdo and Haneef 2013; Zhang et al. 2015). The deposit of solid filter cake on the formation wall contributes to the stability of the wellbore, and reduces the flow of fluids on the permeable formation zone; thereby reducing damage to the formation. For this reason,

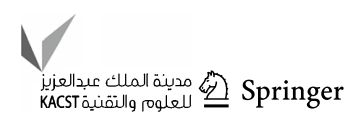


the stability of the well and the damage to the formation are functions of these process explained; which is called the "filtration behavior of drilling fluids" (Barry et al. 2015; Balavi and Boluk 2018). Peng (1990) in his thesis stated that during drilling operations, three types of filtration are encountered. These are the beneath-the-bit, dynamic and static filtrations; and it was also noted that filtrate invasion mostly occurs when filtration starts.

According to Agwu and Akpabio (2018), some cellulosic agro-waste materials have the characteristics to control filtration loss and improve or modify drilling fluids rheology. Their review outlined various studies on the choice of agrowaste materials that can be utilized as filter loss additives in drilling fluids. The gaps outlined in their study prompted the use of cellulosic Cyperus esculentus L. (Tiger nut) as filter loss additive and rheological modifier for both aqueous and non-aqueous drilling mud systems. Cyperus esculentus $\mathrm{L}$. naturally forms thin and low permeability filter cakes. It also has cost and environmental advantages over most conventional fluid loss additives. The Cyperus esculentus L. flour could be good potential additive for formulating low solid aqueous and non-aqueous drilling muds. The aim of this study was to analyze the truism of the above statement and evaluate Tiger nut flour as a functional additive for modification of mud systems rheology and its ability to reduce filtrate while forming low-solids mud systems.

The chemical and physical composition, characteristics and physiochemical properties of Cyperus esculentus have been shown in the various literature (Ezeh et al. 2016; Li et al. 2017; Chinma et al. 2009; Codina-Torrella et al. 2015; Ocloo et al. 2014). Lopéz-Cortés et al. (2013) and Ezeh et al. (2016) in their studies identified that Tiger nut has the capacity to provide good amounts of fatty acids. This property makes it a good lubricant additive in drilling fluids which helps to reduce friction generated during the drilling operations. Tiger nut has the starch property that is underutilized; thus, can modify the viscosity of the drilling fluid system because of the amylose content ( $\mathrm{Li}$ et al. 2017). Ocloo et al. (2014) also noted the solubility of Tiger nut in their study. These properties of Tiger nut make it a choice material for the favorable modification of drilling systems rheology.

\section{Materials and methods}

\section{Materials}

The drilling fluid additives and base fluids for the aqueous and non-aqueous drilling fluids used in the experiments were purchased by Best Land and Services (BLS), a Service company in Port Harcourt, Rivers State, Nigeria. Commercial clays were used as additives for viscosity control and barite as an additive for controlling the mud systems density.
The Tiger nuts used in this study were obtained from the farm market in Zaria, Kaduna State, Nigeria and processed to flour at the University laboratory.

\section{Tiger nut}

Agwu and Akpobio (2018) in their review opined that materials with quantifiable cellulose contents are cost-effective and their use is extensive in the modification of drilling fluid rheology. They also stressed the importance of agro-materials containing cellulose as filtration loss control agents for mud systems. This study identified Tiger nut as an agro-material that can modify rheology (Vendrusculo et al. 2006; Jäder and Järnstorm 2003) and improve filtration loss in mud systems. Having obtained the Tiger nuts, they were sun-dried and ground into a flour form using a grinder, and sieved to 150 microns. The proximate analysis was conducted to determine the moisture and total ash content compositions (Table 1) using AOAC (2000). The sieved samples of the tiger nut were used in formulating aqueous and non-aqueous drilling fluids to investigate its effect on rheological properties and how effective it can be as fluid loss additive in both mud systems. These Tiger nut flours were used in the range from $2 \mathrm{ppb}$ (parts per billion) to $8 \mathrm{ppb}$ for both mud systems; that is, in the concentrations of 2 , 4,6 and $8 \mathrm{ppb}$ to determine the maximum reduction in filtrate volume while applying the various concentrations.

\section{Drilling fluid formulation}

The drilling fluid used for drilling operations is either aqueous or non-aqueous. The typical drilling muds used in the field are formulated with and without the tiger nut flour. A total of sixteen mud systems were formulated, eight (8) aqueous and eight (8) non-aqueous drilling muds. Each mud system has four standard mud systems without tiger nut flour and four (4) mud systems with tiger nut for comparison. Each mud system was prepared in the standard 350-ml laboratory barrel. Each sample was mixed using a standard Hamilton Beach commercial high-speed mixer and a bottom mixer cup. Each mud additive was weighed and gently introduced into the base fluid while the impeller was mixing. The additives and their concentrations for both non-aqueous and aqueous drilling mud systems are tabulated in Tables 2 and 3, respectively. The rheological properties of these mud systems were investigated and the filtration test also conducted (API RP 13B-1 2009, API RP 13I 2004). Fluid filtration properties of the mud systems were

Table 1 Proximate analysis of the Tiger nut flour

\begin{tabular}{lll}
\hline $\mathrm{S} / \mathrm{N}$ & Properties & $\%$ dry matters \\
\hline 1 & Moisture content & 6.80 \\
2 & Total ash content & 2.00 \\
\hline
\end{tabular}


Table 2 Oil-based mud systems (non-aqueous) formulation

\begin{tabular}{|c|c|c|c|c|c|c|c|c|}
\hline \multirow{2}{*}{$\begin{array}{l}\text { Mud weight: } 1.20 \mathrm{SG} \\
\text { Product }\end{array}$} & \multirow{2}{*}{$\begin{array}{l}\text { Oil/water ratio: } \\
\text { Company brand name }\end{array}$} & \multicolumn{2}{|l|}{$75 / 25$} & \multirow[t]{2}{*}{ Mixing order } & \multirow[t]{2}{*}{$\begin{array}{l}\text { Mixing time } \\
(\min )\end{array}$} & \multicolumn{3}{|c|}{$\begin{array}{l}\text { Product concentration for } \\
1 \text { lab bbl ( } 350 \mathrm{mls})\end{array}$} \\
\hline & & S.G. & Unit size & & & Grams & Mils & BBls \\
\hline Base fluid & & 0.805 & bbl & 1 & 4 & 165.5 & 205.6 & 0.6 \\
\hline Organophilic clay & & 1.7 & $\mathrm{lb}$ & & & 8.0 & 4.7 & 0.0 \\
\hline Viscosity modifier & & 0.95 & $\mathrm{lb}$ & & & 1.0 & 1.1 & 0.0 \\
\hline Lime, alkalinity & & 2.3 & $\mathrm{~kg}$ & & & 7.0 & 3.0 & 0.0 \\
\hline Primary emulsifier & & 0.9 & gal & 2 & 2 & 6.0 & 6.7 & 0.0 \\
\hline Secondary emulsifier & & & gal & & & & 0.0 & 0.0 \\
\hline Aqueous phase & & 1 & bbl & 3 & 5 & 68.9 & 68.9 & 0.2 \\
\hline Brine phase calcium chloride & & 3.64 & $\mathrm{~kg}$ & & & 30.3 & 8.3 & 0.0 \\
\hline Rheology modifier & & & gal & & & & 0.0 & 0.0 \\
\hline Barite & & 4.2 & $\mathrm{~kg}$ & 4 & 5 & 0.0 & 0.0 & 0.0 \\
\hline Bridging agent & & 2.7 & $\mathrm{~kg}$ & & & 129.4 & 47.9 & 0.1 \\
\hline Fluid loss agent 1 & & 1.05 & $\mathrm{lb}$ & 5 & 6 & 4.0 & 3.8 & 0.0 \\
\hline \multirow[t]{2}{*}{ Fluid loss agent (if required) } & & & $\mathrm{lb}$ & & & & 0.0 & 0.0 \\
\hline & & & & & & 420.1 & 350.0 & 1.0 \\
\hline
\end{tabular}

Table 3 Water-based mud systems (aqueous) formulation

\begin{tabular}{llllrlr}
\hline Mud weight & PPG & \multicolumn{3}{l}{ Mud type } & & \\
\cline { 4 - 7 } Product name & Brand name & $\begin{array}{l}\text { Product } \\
\text { specific } \\
\text { gravity }\end{array}$ & & \multicolumn{2}{l}{$\begin{array}{l}\text { Product concentration lab } \\
\text { barrel }\end{array}$} \\
\cline { 4 - 7 } & & & lbs/bbl & Grams & Mils \\
\hline Water & Water & 1 & 325.13 & 325.13 & 325.13 \\
Viscosifier 2 & & 1.5 & 1.50 & 2.00 & 1.33 \\
Fluid loss additive 1 & & & & & \\
Alkalinity & Soda ash & 2.5 & 0.25 & 0.25 & 0.10 \\
NACL & NACL & 3.31 & 14.54 & 14.54 & 4.37 \\
Other & Caustic soda & 2.13 & 0.25 & 0.25 & 0.12 \\
Other & X-CIDE 102 & 1.07 & 0.25 & 0.25 & 0.23 \\
Barite & Barite local & 3.9 & 70.00 & 70.00 & 17.50 \\
\hline
\end{tabular}

evaluated using API Filter Press for aqueous mud systems and HPHT filter press for the non-aqueous mud systems. The volume of filtrate collected over time was measured to know the mud systems filtration characteristics before and after applying the Tiger nut flour.

\section{Modeling the fluid loss properties}

Filtration and accumulation of mudcake in the search for oil and gas are critical to the success of drilling operation. Filtration and accumulation of mudcake have been widely studied in recent years, but due to the complexity of the problem and a large number of factors, it has not yet been fully understood. There are various models of filtration and mudcake buildup (Jiao and Sharma 1994; Dewan and
Chenevert 2001; Civan 2016; Jaffal et al. 2017). The accuracy of the results of the model depends on the validity of the assumptions used, especially those that are related to the properties of the mudcake, such as porosity and permeability. Because of the complexity of mudcake accumulation and the difficulty in measuring properties during filtration, there is a need for experimental work that goes hand in hand with modeling for better understanding. Due to the impact on the costly problems associated with the wellbore, a better understanding of the filtration and accumulation of mudcakes is of great importance. Classic filtration model was adopted in this study. Jaffal et al. (2017) gave extensive details of the classic filtration model.

\section{Results and discussion}

The results from the experiments and their discussions are presented in this section.

\section{Rheological properties}

The phenomenon of filtrate invasion of the reservoir rock is also significantly influenced by the rheological properties. The mud systems formulated and applied in this study showed a trend of high viscosity at lower shear rates (Fig. 1); thus, can be said to be non-Newtonian fluids that can adequately suspend and transport drilling cuttings from wellbore to the surface (Huo et al. 2018).

Mud systems with yield point (YP) greater than the plastic viscosity (PV) exhibit partial flocculation of solids; this often results in clogging of the drill string. The YP values of 
the mud systems investigated were lower than the PV; thus, flocculation will not occur when these mud systems are used for drilling operations (Table 4). The flow behavior index, $n$ and the consistency factors, $k$ for the optimum concentrations are shown in Fig. 1.

From this study, it was deduced that the consistency index $(k)$ for the non-aqueous mud systems was higher than the aqueous mud systems. Huo et al. (2018) stated that the higher value of $k$, the more favorable it is for drilling operations and for effective wellbore cleaning. Both mud systems exhibited low fluid behavior index $(n)$, which indicates a high shear thinning property; and this is also emphasized in Fig. 2. It showed that the viscosity of the mud systems decreased when shear rates were high. There is a progressive improvement as the concentration of the Cyperus esculentus increased from 2 to $6 \mathrm{ppb}$. Figure 3 shows the yield point from the plot of shear rate against shear stress. The point at the shear stress axis where the curve initiates
Fig. 1 The flow curve for a nonaqueous and $\mathbf{b}$ aqueous drilling fluid systems

Table 4 The drilling mud systems rheological properties

Fig. 2 The mud systems shear thinning characteristics for a aqueous and $\mathbf{b}$ non-aqueous drilling muds (a)

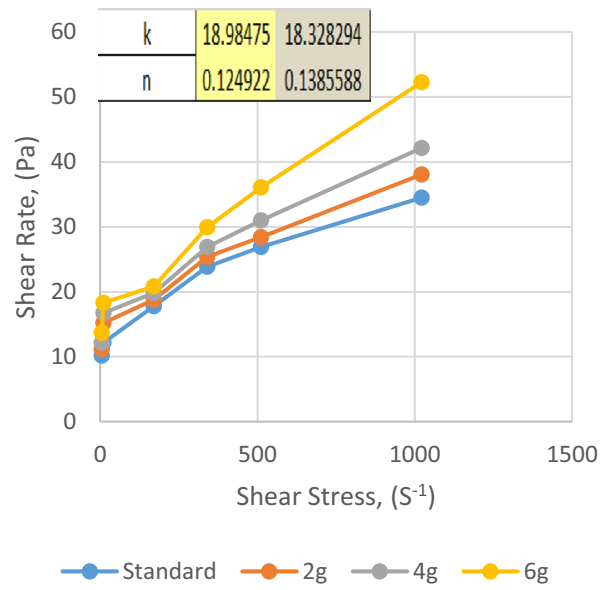

(b)

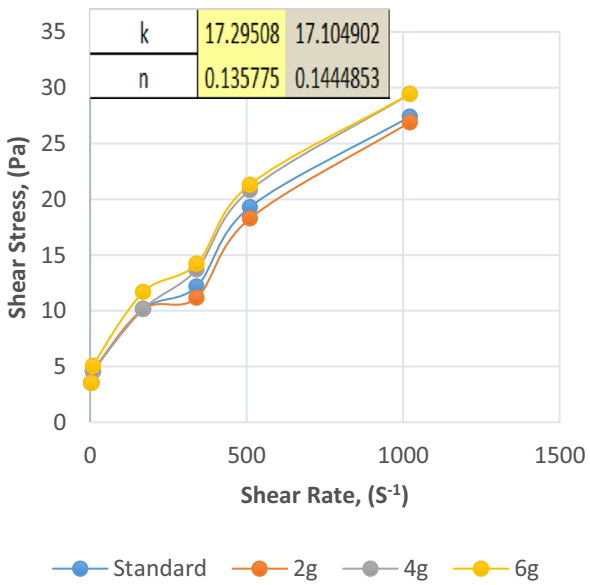

\begin{tabular}{|c|c|c|c|c|c|c|c|c|c|c|}
\hline \multirow[t]{2}{*}{ Properties } & \multicolumn{5}{|c|}{ Aqueous mud } & \multicolumn{5}{|c|}{ Non-aqueous mud } \\
\hline & Standard & $2 \mathrm{~g}$ & $4 \mathrm{~g}$ & $6 \mathrm{~g}$ & $8 \mathrm{~g}$ & Standard & $2 \mathrm{~g}$ & $4 \mathrm{~g}$ & $6 \mathrm{~g}$ & $8 \mathrm{~g}$ \\
\hline Mud weight (ppg) & 9.5 & 9.56 & 9.61 & 9.72 & 9.8 & 10 & 10.05 & 10.10 & 10.21 & 10.29 \\
\hline Specific gravity & 1.15 & 1.16 & 1.17 & 1.18 & 1.19 & 1.2 & 1.21 & 1.22 & 1.23 & 1.24 \\
\hline Apparent viscosity & 27 & 26.5 & 29 & 29 & 30 & 34 & 38 & 42 & 52 & 66 \\
\hline Plastic viscosity (cP) & 22 & 23 & 24 & 22 & 22 & 27 & 31 & 34 & 36 & 57 \\
\hline Yield point $\left(100 \mathrm{lb} / \mathrm{ft}^{2}\right)$ & 10 & 7 & 10 & 14 & 16 & 14 & 13 & 15 & 31 & 17 \\
\hline
\end{tabular}

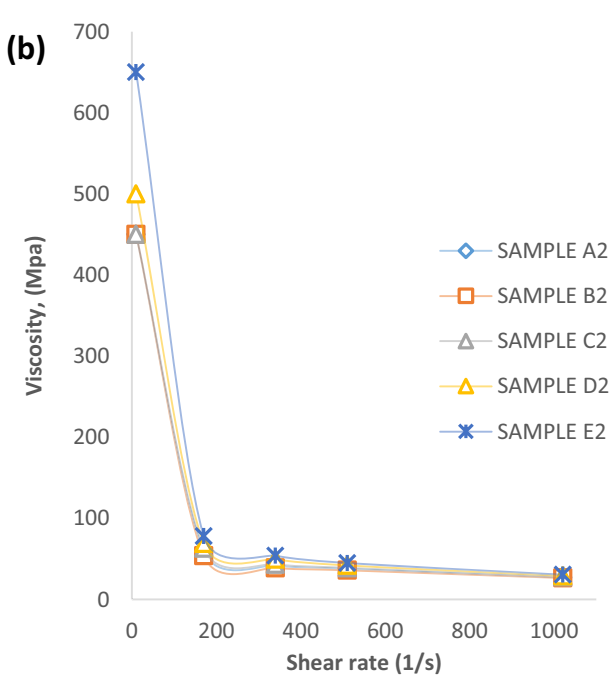




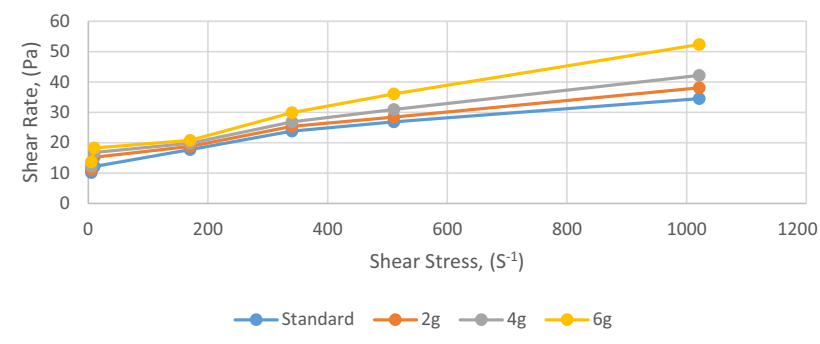

Fig. 3 A plot of shear rate against shear stress

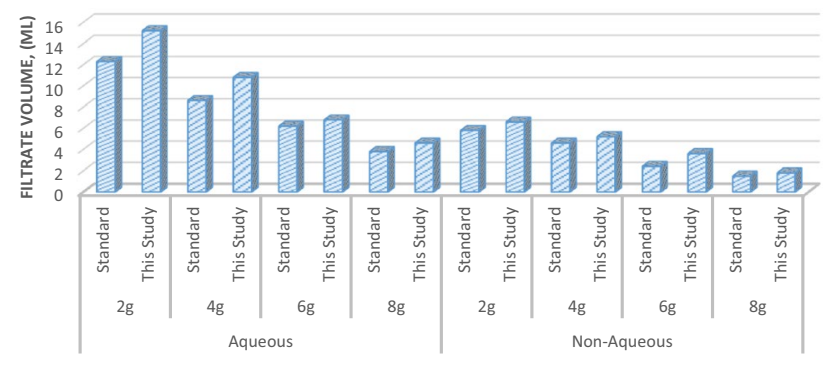

Fig. 4 The filtration volume from the filtration test for aqueous and non-aqueous drilling mud systems compared with standard

from is the yield point of each mud samples formulated with the Tiger nut.

The shear stress changes more prominently at low shear rate due to the strong repulsive interactions among the additives; while at high shear rates, the change in shear stress was not prominent due to the alignment of the additives (Fig. 3).

\section{Filtrate loss test}

Most studies have their emphasis on how to reduce the volume of filtrate; thus, a lot of additives have been proposed to optimize most mud systems. Figure 4 shows the filtration results of the API filter press for aqueous mud system and high-temperature high-pressure filter press for non-aqueous mud system. These tests are used to simulate the ability of the mud systems to control filtration loss into the formation. The filtrate volume obtained when Cyperus esculentus was used as fluid loss additive at different concentrations were compared with the standard.
Figure 4 shows the performance of the proposed filtration loss additive and standard mud systems used in the field. A reduction in filtrate volume was recorded for both aqueous and non-aqueous mud systems. Thus, increase in concentration of cellulosic Cyperus esculentus reduces the volume of filtrate that will enter the formation pores.

The filter cake thickness and filtrate from the filtration test is tabulated in Table 5.

The increase in the Cyperus esculentus concentration from 2 to $8 \mathrm{~g}$ shows a progressive reduction in filtrate volume of both mud systems; though, the non-aqueous mud system exhibits a close trend to the standard. At a 4-ppb concentration of Cyperus esculentus, both showed a significant improvement in filtrate volume reduction. Physical observation shows that the filter cake thickness for the non-aqueous mud systems was $1 \mathrm{~mm}$ while that of aqueous mud systems was $2.5 \mathrm{~mm}$. The cake nature was moderately hard and firm for both mud systems. Thick filter cake will increase filtration into the formations and enhance the chances of differential sticking. Thus, drilling fluids that produce thin filter cakes are desirable for enhanced drilling operations.

\section{Modeling filtration behavior}

Monitoring and controlling the rheological and filtration characteristics of drilling muds is essential for the success of oil and gas well drilling operations. For smooth drilling, the desired filtration characteristics are minimal fluid loss, a thin, waterproof filter cake and a low permeability filter. The permeability of the filter was determined by the Darcy's law. A linear relationship exists between the volume $(\mathrm{ml})$ of the filtrate and the square root.

$\frac{\mathrm{d} V_{\mathrm{f}}}{\mathrm{d} t}=\frac{k A \Delta P}{\mu h_{\mathrm{c}}}$,

where $V_{\mathrm{f}}\left(\mathrm{cm}^{3}\right)$ is the filtrate volume, $k(\mu \mathrm{D})$ is the permeability of filter cake, $\Delta P(\mathrm{~Pa})$ is the pressure drop across the filter cake, $A\left(\mathrm{~cm}^{2}\right)$ is the area of filter medium, $t(\mathrm{~s})$ is the time for filtration, $h_{\mathrm{c}}(\mathrm{cm})$ is the thickness of filter cake, and $\mu(\mathrm{Pa} \mathrm{s})$ is the viscosity of filtrate.

Concerning the influence of solids, the Cyperus esculentus content was varied and the filtrate volume for

Table 5 Filter cake thickness and filtrate volume compared with standard

\begin{tabular}{lllll}
\hline Quantity $(\mathrm{g})$ & TNA $(\mathrm{mls})$ & Filter cake characteristics & Standard (mls) & Filter cake characteristics \\
\hline 2 & 6.6 & Cake thickness 1 mm (moderately hard, firm) & 5.8 & Cake thickness 1 mm (moderately hard, firm) \\
4 & 5.2 & Cake thickness 1 mm (moderately hard, firm) & 4.6 & Cake thickness 1 mm (moderately hard, firm) \\
6 & 3.6 & Cake thickness 1 mm (moderately hard, firm) & 2.4 & Cake thickness 1 mm (moderately hard, firm) \\
8 & 1.8 & Cake thickness 1 mm (moderately hard, firm) & 1.5 & Cake thickness 1 mm (moderately hard, firm) \\
\hline
\end{tabular}




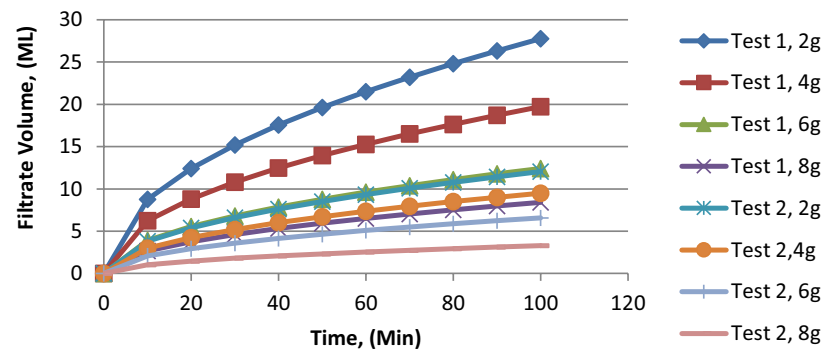

Fig. 5 Filtrate volume results for the effect of Cyperus esculentus concentration

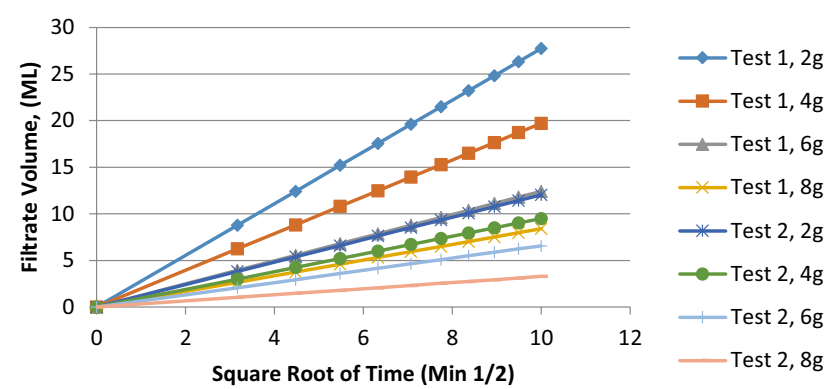

Fig. 6 Filtration volume plotted against the square root of time

aqueous mud at different concentrations was labeled test 1 while the non-aqueous is test 2 . The results are presented in Fig. 5.

Initially, the rate of fluid loss during the filtration experiment was high during the first $5 \mathrm{~min}$ of all dispersions. This initial high rate of fluid loss is due to the absence of thin filter cake at the beginning of the filtration experiment (Fig. 5). During the filtration experiment, due to the formation of a filter cake, the rate of fluid loss decreased compared with the start of the experiment.

The linear relationship between the volume of the filtrate and the ratio of squares over time (Darcy's law) was confirmed by superimposing the square root of time and the volume of the filtrate shown in Fig. 6.

Figure 6 shows the application of the classic filtration with emphasis on the initial $30 \mathrm{~min}$. It is a plot of filtration volume against the square root of time. The plot was observed to be linear which shows that the results were in line with the model.

\section{Conclusion}

Aqueous and non-aqueous drilling fluid systems have been formulated using Cyperus esculentus as filtration additive. The results showed that Cyperus esculentus exhibits a progressive trend for both mud systems; but it is more effective in non-aqueous drilling mud system. The experimental study on the static filtration was to investigate the effects of Cyperus esculentus on filtrate volume and mudcake generated. The rheological properties of the drilling mud systems showed a progressive trend as the concentrations of the additive was increased from 2 to $8 \mathrm{ppb}$. It was also observed from the API and HPHT filter press test that the increase in the concentration exhibits a progressive trend that can be compared with the standard. The classic filtration model showed that both mud systems results from the experiment were fit for the adopted model.

Acknowledgements The authors would like to thank Covenant University Centre for Research Innovation and Discovery (CUCRID) Ota, Nigeria for its support in making the publication of this research possible.

Open Access This article is distributed under the terms of the Creative Commons Attribution 4.0 International License (http://creativeco mmons.org/licenses/by/4.0/), which permits unrestricted use, distribution, and reproduction in any medium, provided you give appropriate credit to the original author(s) and the source, provide a link to the Creative Commons license, and indicate if changes were made.

\section{References}

Abdo J, Haneef MD (2013) Clay nanoparticles modified drilling fluids for drilling of deep hydrocarbon wells. Appl Clay Sci 86:76-82

Adams N, Eustes AW (2011) In: Mitchell RF, Miska SZ (eds) Drilling problems in fundamentals of drilling engineering, SPE textbook series, vol 12, Chapter 10, Sosiety of Petroleum Engineers, 222 Palisades Creek Drive Richardson. Taxas, USA, p 625-676

Agwu OE, Akpabio JU (2018) Using agro-waste materials as possible filter loss control agents in drilling muds: a review. J Pet Sci Eng 163:185-198

Alsaba M, Nygaard R, Hareland G, Contreras O (2014) Review of lost circulation materials and treatments with an updated classification. In: Paper AADE-14-FTCE-25 presented at the 2014 AADE fluids technical conference and exhibition, Houston, Texas

AOAC (2000) Official methods of analysis, 17th edn. AOAC International, Gaithersburg

API RP 13B-1 (2009) Recommended practice for field testing of water-based drilling fluids, 4 edn. American Petroleum Institute, pp 8-10

API RP 13I (2004) Recommended practice for laboratory testing of drilling fluids, 7 th edn. American Petroleum Institute, pp 11-12

Balavi H, Boluk Y (2018) Dynamic filtration of drilling fluids and fluid loss under axially rotating crossflow filtration. J Pet Sci Eng 163:611-615

Barry MM, Jung Y, Lee JK, Phuoc TX, Chyu MK (2015) Fluid filtration and rheological properties of nanoparticle additive and intercalated clay hybrid bentonite drilling fluids. J Pet Sci Eng 127:338-346

Caenn R, Darley HC, Gray GR (2011) Composition and properties of drilling and completion fluids. Gulf Professional Publishing, Houston

Chinma CE, Adewuyi O, Abu JO (2009) Effect of germination on the chemical, functional and pasting properties of flour from brown 
and yellow varieties of tigernut (Cyperus esculentus). Food Res Int 42:1004-1009

Civan F (2016) Reservoir formation damage, 3 edn. Gulf Publishing Company, Houston

Codina-Torrella I, Guamis B, Trujilo AJ (2015) Characterization and comparison of tiger nut (Cyperus esculentus L.) from different geographical origin: physico-chemical characteristics and protein fractionation. Ind Crops Prod 65, 406-414

Dewan J, Chenevert M (2001) A model for filtration of water-base mud during drilling: determination of mudcake parameters. Petrophysics 42(3):237-250

Ezeh O, Gordon MH, Niranjan K (2016) Enhancing the recovery of tiger nut (Cyperus esculentus) oil by mechanical pressing: moisture content, particle size, high pressure and enzymatic pre $=$ treatment effects. Food Chem 194:354-361

Huo J-H, Peng Z-G, Ye Z-B, Feng Q, Zheng Y, Zhang J, Liu X (2018) Investigation of synthesized polymer on the rheological and filtration performance of water-based drilling fluid system. J Pet Sci Eng 165:655-663

Jäder J, Järnström L (2003) The influence of thickener addition on filter cake formation during dewatering of mineral suspensions. Appl Rheol 13:125-131

Jaffal HA, El Mohtar CS, Gray KE (2017) Modeling of filtration and mudcake buildup: an experimental investigation. J Nat Gas Sci Eng 38:1-11

Jiao D, Sharma M (1994) Mechanism of cake buildup in crossflow filtration of colloidal suspensions. J Colloid Interface Sci 162(2):454-462

Li X, Fu J, Wang Y, Ma F, Li D (2017) Preparation of low digestible and viscoelastic tigernut (Cyperus esculentus) starch by Bacillus acidopullulyticus pullulanase. Int J Biol Macromol 102:651-657
Lopéz-Cortés I, Salazar-García DC, Malheiro R, Guardiola V, Pereira JA (2013) Chemometrics as a tool to discriminate geographical origin of Cyperus esculentus L. based on chemical composition. Ind Crops Prod 51:19-25

Luo Z, Pei J, Wang L, Yu P, Chen Z (2017) Influence of an ionic liquid on rheological and filtration properties of water-based drilling fluids at high temperatures. Appl Clay Sci 136:96-102

Ocloo FCK, Okyere AA, Asare IK (2014) Physicochemical, functional and pasting properties of flour produced from gamma irradiated tiger nut (Cyperus esculentus L.). Radiat Phys Chem 103:9-15

Okoro EE, Dosunmu A (2014) Experimental analysis of shale for evaluating shale drilling fluid interaction in Agbada Formation. Br J Appl Sci Technol 4(35):4878-4907

Peng SJ (1990) Filtration properties of water based drilling fluids. Submitted for the Degree of Doctor of Philosophy at Heriot-Watt University on Completion of Research in the Department of Petroleum Engineering

Vendrusculo AT, Hotza D, Gomes CM, Quadri MGN (2006) Rheology of star fruit pulp (Averrhoa carambola L.). Appl Rheol 16:26-31

Zhang GZ, Zhang ZP, Fu M, Ye X, Liao LB (2015) Comparative study on the use of cationic-nonionic-organo-montmorillonite in oilbased drilling fluids. Appl Clay Sci 116:257-262

Publisher's Note Springer Nature remains neutral with regard to jurisdictional claims in published maps and institutional affiliations. 